УДК 519.246.8

Свиденко А.В.,

Наиіональний технічний університет Украйни «КПІ»

\title{
МОДЕЛЮВАННЯ ДИНАМІКИ ОПТОВИХ ЦІН НА РИНКУ НАФТОПРОДУКТІВ УКРАЇНИ
}

\author{
МОДЕЛИРОВАНИЕ ДИНАМИКИ ОПТОВІХ ЦЕН НА РЫНКЕ \\ НЕФТЕПРОДУКТОВ УКРАИНЫ
}

\section{MODELLING WHOLESALE PRICES IN THE UKRAINIAN OIL MARKET}

У даній статті досліджується механізм формування оптових изін на ринку нафтопродуктів Украӥни. Розглянуто структуру оптового ринку та виділено основні його складові. Визначено фактори, щзо впливають на оптову иіну та основні етапи ї формування. Розглянуто застосування коінтеграційного підходу до моделювання поведінки оптових цін на пальне за умови їх асиметричної поведінки відносно світових цін. Запропоновано математичну модель, щэо базується на моделі корекції помилки, яка дозволяє коректно описувати динаміку иін на нафтопродукти в дрібному гурті через введення механізму розділення режимів роботи моделі. Показано наявність асиметричної поведінки цін в оптовому сегменті ринку нафтопродуктів. Визначено час реакиії ринку на збурення та причини інерційності изін по відношенню до коливань цін виробників середньої амплітуди. Показано можливість використання моделі для побудови короткострокових прогнозів оптових иін.

Ключові слова: ринок нафтопродуктів, оптові ціни, коінтеграція, ЕСМ-модель, асиметрія цін.

В данной статье исследуется механизм формирования оптовых иен на рынке нефтепродуктов Украины. Рассмотрено структуру оптового рынка и раскрыто основные его составляющие. Показаны факторы, влияющие на оптовую иену, а такље показаны основные этапы ее формирования. Рассмотрено применение коинтеграционного подхода $\kappa$ моделированию поведения оптовых иен на топливо в условиях их асимметрии по отношению $\kappa$ мировым ценам. Предложено математическую модель, которая базируется на модели коррекции ошибки и позволяет адекватно описывать динамику цен на нефтепродукты в мелком опте с помощьью введения механизма переключения режимов работы модели. Показано наличие асимметрии цен в оптовом сегменте рынка нефтепродуктов, и определено время реакции рынка и инерционность иен по отношению к колебаниям иен производителей средней амплитудьл. Описано возможность использования модели для краткосрочного прогнозирования оптовых иен.

Ключевые слова: рынок нефтепродуктов, оптовые цены, коинтеграция, ЕСМмодель, асимметрия цен.

This article investigates the mechanism of wholesale pricing in the Ukrainian oil market. Structure and main components of the Ukrainian oil market are considered. Factors and main stages of wholesale pricing are identified. Application of cointegration approach for wholesale fuel prices behaviour modelling with asymmetric adjustment relative to world prices is 
considered. A mathematical model that permits a correct description of the small wholesale petroleum prices dynamics is developed. Asymmetric behaviour of oil wholesale prices is revealed. The time of market response to disturbances and sluggishness of price adjustments relative to average amplitude of producer prices fluctuations are estimated. The possibility of model implementation for short-term wholesale prices forecasting is showed.

Key words: oil market, wholesale prices, cointegration, ECM-model, price asymmetry.

Вступ. Присутність значної кількості економічних суб'єктів на сучасному ринку нафтопродуктів України, де конкуренція між учасниками йде далеко не завжди за правилами вільної конкуренції та суттєва інтегрованість економіки України в світову економіку визначально впливають на поведінку цін нафтопродуктів. Проведені за останні роки дослідження $[3,4,5]$ чітко вказали на суттєву нестаціонарність поведінки цін на нафтопродукти. Проведений в [4] факторний аналіз показав, що основними джерелами збурень рівноваги цього ринку є зовнішні чинники, в першу чергу ціна на сиру нафту на світових біржах та обмінний курс валют. Характер поведінки цін на нафтопродукти в Україні ускладнюється також внаслідок кооперативних дій агентів ринку. Це проявляється в ефекті так званої асиметрії цін, коли при більш-менш значному стрибку значення зовнішнього фактора відбувається швидкий підйом роздрібної ціни і повільне опускання роздрібної ціни, коли відбувається зниження значення зовнішнього фактора. Це явище притаманне для ринків нафтопродуктів багатьох країн. Для оцінки впливу цього явища на поведінку ціни в роздрібному сегменті використовуються агенті моделі.

Постановка завдання. Метою дослідження $\epsilon$ розкриття механізму формування оптової ціни на ринку нафтопродуктів України та побудова моделі поведінки ціни дрібного гурту, для забезпечення більш повного охоплення механізму ціноутворення на ринку нафтопродуктів.

Методологія. Основою для побудови моделі являється коінтеграційний підхід до аналізу часових рядів та використання моделі коригування помилки для описання поведінки цін.

Результати дослідження. Як показано в [4] ціни на нафтопродукти на ринку України коінтегровані з курсом валют та цінами на нафту, що вказує на існування моделі корекції помилки для моделювання їх поведінки. Запропонована модель дозволяє прогнозувати роздрібні ціни до 14 днів, однак дана модель не враховує такі особливості ринку нафтопродуктів, як часті маніпуляції з якістю палива, змови між мережами, завищення ціни через зловживання монопольним становищем та інше. Для врахування даних факторів використовується агент ний підхід, де можливо детальне описанні поведінки кожного економічного агенту. В роботі [5] розглядається побудова агентної моделі для роздрібного ринку нафтопродуктів, оскільки даний сегмент ринку найбільш спостережуваний. Однак для дослідження поведінки 
ринку в цілому необхідно реалізувати механізми поведінки й на оптових ринках, що являється досить проблематичним в зв'язку 3 низькою спостережуваністю ринків. Таким чином необхідно шукати інший підхід до описання поведінки ціни в оптовому сегменті.

Розрізняють чотири основні ринки нафтопродуктів в залежності від об'ємів поставок[6]: ринок великого гурту, середнього гурту, малого гурту та роздрібний ринок. При проходженні пального через кожен з ринків до ціни додаються специфічні лише для даного ринку витрати. I хоча окремі процеси утворення роздрібної ціни можуть проходити не всі стадії (велика мережа АЗС зазвичай замовляє пальне $з$ заводу та має власні нафтобази), але структура витрат залишається незмінною.

Ринок великого гурту. Характеризується торгівлею нафтопродуктами в великих об’ємах безпосередньо з заводу. Більшість пального реалізується по довгостроковим контрактам.

Собівартість випуску нафтопродуктів на українських НПЗ залежить як від ціни на імпортовану нафту та нафту власного виробництва. Для переробки в Україну з 2010 по 2014 імпортувалася нафта з Казахстану(марка CPC Blend), Азербайджану(марка Azeri Light) та Росії(марка Urals). Нафта українського видобутку для внутрішніх потреб реалізується на щомісячних аукціонах, де стартова ціна зав'язана на котирування нафти марки Brent.

Згідно податкового кодексу на вироблене в Україні, або імпортоване пальне накладається акциз та екологічний податок, сума яких варіюється в залежності від виду пального та екологічного класу. Так в 2014 році для бензинів акциз складає 198 євро за тону, а екологічний податок - 83 грн/т. Разом $з$ цим в податковому кодексі зазначено, що для нафтопродуктів база оподаткування ПДВ включає як акциз так і екологічний податок.

Ринок середнього гурту. На цей ринок виходять трейдери та імпортери. Продаж нафтопродуктів здійснюється з залізничних станцій в об'ємах більше однієї цистерни(60т).

Основним індикатором цін на європейському ринку нафтопродуктів $\epsilon$ агенція Platts, котирування якої беруться за основу при укладенні контрактів, а ціна на кордоні країни-імпортера буде визначатися по принципу Platts + премія.[7] За оцінками експертів для бензинів 3 поставкою до українського кордону дана премія складає $\$ 60$ за тонну по північноєвропейському базису.

Таким чином ціни в великому гурті для імпортного ресурсу та ресурсу власного виробництва розраховується наступним чином:

$$
F C A=\left(C P T \cdot M B^{\text {doll }}+A z \cdot N B U^{\text {euro }}+E C O+T Z+L s+M s\right)(1+V A T)
$$




$$
F C A=\left(\frac{E X W}{1+V A T}+L s+M s\right)(1+V A T), \text { для українських НПЗ }
$$

де

$F C A$ - ціна на пальне на умовах FCA (франко-перевізник, Інкотрермс2010), грн/т,

CPT - Ціна на імпортне пальне на умовах поставки СРТ

(Фрахт/перевезення оплачені до, Інкотрермс-2010) на кордоні України, грн/дол.,

$M B^{\text {doll }}$ - курс долара США на міжбанківській валютній біржі,

$N B U^{\text {euro }}$ - курс євро НБУ,

$A z$ - ставка акцизу на нафтопродукти, євро/т,

$E C O$ - ставка екологічного податку, грн/т,

$T Z$ - витрати, пов'язані з митним оформленням вантажу та перевантаженням пального на кордоні,

$L s$ - витрати за доставку пального до станції відвантаження, грн/т,

$M s$ - надбавка трейдера та інші витрати, грн/т,

$E X W$ - ціна пального в великому гурті на умовах поставки EXW(Франко завод, Інкотрермс-2010), грн/т.

Ринок дрібного гурту. Паливо реалізується з доставкою бензовозами на відстань до 100-200 км від місця зберігання. В даному сегменті відбувається перехід від тонн до літрів, що дозволяє деякі маніпуляції з ціною, адже для точного розрахунку вихідної ціни потрібно знати конкретну густину пального під час реалізації, оскільки вона залежить від температури. I хоча при виробництві пального видається паспорт відповідності, де вказується густина за нормальних умов, однак допуск в стандартах і відхилення температури реалізації в $10^{\circ} \mathrm{C}$ можуть дати відхилення в ціні до 0,7 грн/л.

Таким чином розрахунок ціни дрібного гурту проводиться наступним чином:

$$
P=\left(\frac{F C A}{(1+V A T) \cdot(1-l o s s)}+L s+P R V+S+M s\right) \frac{(1+V A T) \cdot R o(T)}{1000}
$$

де

$P$ - ціна дрібного гурту, грн/л

$F C A$ - ціна на пальне на умовах FCA, грн/т

$L s$ - витрати за доставку пального до станції відвантаження, грн/т

$M s$ - надбавка трейдера та інші витрати, грн/т

loss - втрати під час доставки, переливу та зберігання

$P R V$ - витрати на перевалку, грн/т

$R o(t)$ - густина пального за температури $t$, г/см3 
$T$ - усереднена за 7 днів середньодобова температура по Україні на день встановлення ціни, ${ }^{\circ} \mathrm{C}$

При проходженні ресурсу по ринкам відбувається деяка затримка в ціні. Так в середньому гурті затримка складає в середньому 4-6 днів, а в дрібному 3-5 дні. Таким чином загальний лаг ціни в опті складає 8-12 днів.

Формули (1), (2) та (3) дають можливість розрахувати справедливу ціну 3 точки зору покупця, однак враховуючи специфіку ринку реальна ціна дещо відрізняється від розрахункової через непрозорість ціноутворення, наявності асиметрії цін та інші фактори, що викликають інерційність ринку.

Модель. Описана в [4] модель ціни на нафтопродукти базується на коінтеграції цін з курсом валют та цінами на нафту. Однак, як було зазначено вище, поведінка цін великого гурту в Свропі дещо відрізняється від поведінки цін на нафту та використовуються різні курси валют для визначення податків, тому за основу будемо брати перерахунок ціни з великого гурту з подальшим використанням в моделі корегування помилки, оскільки остання дозволяє моделювати довгострокові залежності 3 врахуванням локальних характеристик поведінки рядів.[8]

В 2013-2014 рр. більше 70\% нафтопродуктів імпортується, що в значній мірі впливає на поведінку цін на внутрішньому ринку. Тому за основу в розрахунку моделі будуть використовуватись ціни на кордоні України за умовами поставки СРТ.

Як зазначено в [1,2] на роздрібному ринку нафтопродуктів більшості країн присутня асиметрія цін. Для України це теж характерно. Тому для врахування цього факту необхідно дещо доповнити базову модель взявши за основу модель корекції помилки та додати механізм перемикання режимів.

$$
\Delta y_{t}=\left\{\begin{array}{l}
\sum_{i=0}^{\operatorname{lag}} \alpha_{t-i}^{-} \Delta C P T_{t-i}^{-}+\sum_{i=1}^{l a g} \beta_{t-i}^{-} \Delta y_{t-i}^{-}-\lambda^{-} E C T_{t-1}+\varepsilon_{t}, \text { якщо } E C T_{t-1}<r \\
\sum_{i=0}^{\operatorname{lag}} \alpha_{t-i}^{+} \Delta C P T_{t-i}^{+}+\sum_{i=1}^{l a g} \beta_{t-i}^{-} \Delta y_{t-i}^{+}-\lambda^{+} E C T_{t-1}+\varepsilon_{t}, \text { якщо } E C T_{t-1} \geq r
\end{array}\right.
$$

В моделі оцінюються параметри для двох станів: при ціни та при зниженні. Параметри $\alpha^{-}$та $\beta^{-}$відповідають за поведінку ціни при зниженні, а $\alpha^{+}$та $\beta^{+}$- при зростанні. Перемикання режимів здійснюється за рахунок введення параметра $r$, що відповідає за границю розділення режимів. Оцінки проводились на даних за період з 2011 по 2012 роки. В таблиці показано значущі коефіцієнти моделі з рівнем значимості. Лаг в моделі визначався за допомогою критерію AIC та в даному випадку складає 24 дні. 
Таблиця

Значимі параметри моделі

\begin{tabular}{|l|c|c|c|}
\hline \multicolumn{1}{|c|}{ Коефіцієнт } & Значення & $\begin{array}{c}\text { Значення } \\
\text { t-статистики }\end{array}$ & $\mathrm{P}$ \\
\hline alpha.t_7.pos & 0,020 & 2,196 & 0,028 \\
\hline alpha.t_9.pos & 0,025 & $-2,741$ & 0,006 \\
\hline alpha.t_14.neg & 0,024 & 2,211 & 0,027 \\
\hline alpha.t_20.neg & $-0,021$ & $-1,938$ & 0,053 \\
\hline beta.t_1.pos & 0,214 & 5,308 & 0,000 \\
\hline beta.t_4.pos & $-0,083$ & $-1,937$ & 0,053 \\
\hline beta.t_7.pos & 0,164 & 3,841 & 0,000 \\
\hline beta.t_8.pos & 0,135 & 3,13 & 0,002 \\
\hline beta.t_10.pos & $-0,079$ & $-1,821$ & 0,069 \\
\hline beta.t_13.pos & 0,117 & 2,711 & 0,007 \\
\hline beta.t_14.pos & 0,100 & 2,314 & 0,021 \\
\hline beta.t_16.pos & $-0,128$ & $-3,06$ & 0,002 \\
\hline beta.t_20.pos & $-0,089$ & $-2,315$ & 0,021 \\
\hline beta.t_21.pos & 0,122 & 3,185 & 0,001 \\
\hline beta.t_22.pos & $-0,106$ & $-2,733$ & 0,006 \\
\hline beta.t_1.neg & 0,279 & 4,581 & 0,000 \\
\hline beta.t_6.neg & 0,229 & 3,649 & 0,000 \\
\hline beta.t_7.neg & 0,198 & 3,112 & 0,002 \\
\hline ECT.t_1.pos & $-0,011$ & $-3,263$ & 0,001 \\
\hline ECT.t_1.neg & $-0,015$ & $-5,473$ & 0,000 \\
\hline
\end{tabular}

Результат моделювання зображено на рисунку. За основу бралися статистика цін дрібного гурту на бензин А-95 в 2011-2013 роках та статистика цін на Gasoline 10ppm на кордоні України на умовах поставки СРТ, яка в подальшому перераховувалась за формулами (1-3) в ціну дрібного гурту без врахування маржі трейдера на кожному 3 етапів та витрат на транспортування. Період з 01.01.2013 являється тестовим для моделі і показує високу точність моделі (коефіцієнт кореляції складає - 0,99).

Як зазначено вище, загальний лаг між рядами складає 12 днів. Таким чином використовуючи модель можливо прогнозувати поведінку ціни дрібного гурту до 10 днів. 


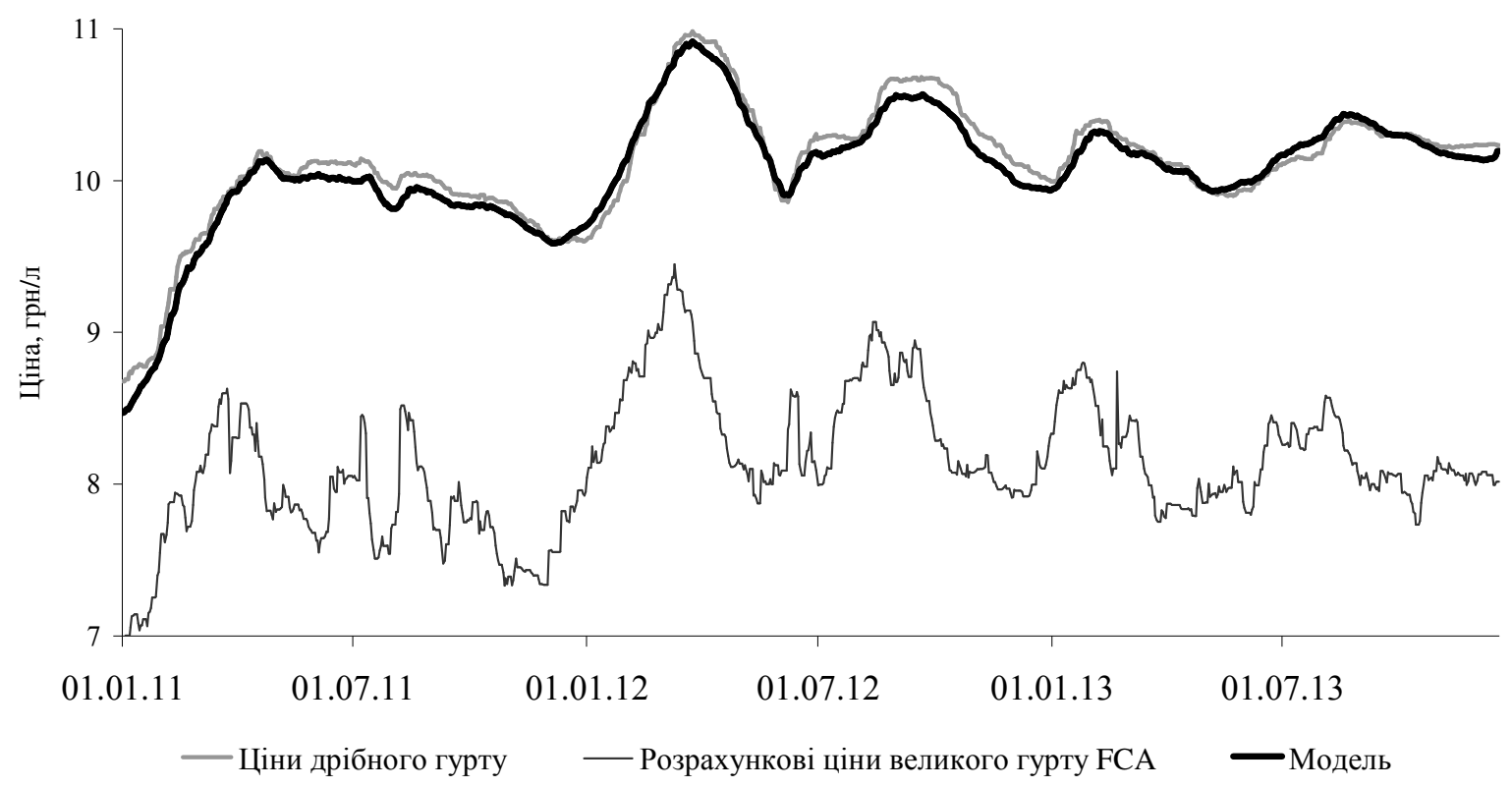

Рисунок. Результат моделювання ціни бензину А-95 дрібного гурту з 2011 по 2013 роки.

Як бачимо спостерігається і ефект асиметрії. Так при відповідних коефіцієнтах, що відповідають за періоди зростання спостерігаємо більший вплив, ніж в періоди зниження ціни. Слід також зазначити, що не лише роздрібні ціни, а й ціни дрібного гурту проявляють деяку інерційність при коливаннях цін великого гурту з досить незначною амплітудою.

Висновки. Наукова новизна даної статті полягає в розкритті механізму формування оптових цін на ринку нафтопродуктів та розробка математичної моделі для їх опису процесу їх формування. Використання моделі корекції помилки дозволяє побудувати модель поведінки ціни дрібного гурту, яка 3 досить високою точністю дозволяє визначати та прогнозувати ціни дрібного гурту до 10 днів. Характерним також є факт наявності асиметрії й в оптовому сегменті ринку. Разом з розробкою агентної моделі роздрібного сегменту покривається весь механізм ціноутворення на ринку нафтопродуктів, що $є$ перспективою для подальших досліджень в області функціонування даного ринку, визначення особливостей впливу таких факторів, як курси валют ставки податків та ціни на НПЗ на поведінку роздрібних цін нафтопродукти.

\section{Література:}

1. Bacon, R. The asymmetric Speed of Adjustment of UK Retail Gasoline Prices to Cost Changes / Bacon R., Rockets // Energy Economics. - 1991. - Vol. 13, pp. 211-218.

2. Borenstein, S. Prices Respond Asymmetrically To Crude Oil Price Changes? / Borenstein S., Cameron A., Gilbert R. // National Bureau of Economic Research. - 1992, Working Paper No. 4138. 
3. Гальчинський, Л.Ю. Факторний аналіз формування цін на світовому ринку нафти / Гальчинський Л.Ю., Веременко І.А. // Економічний вісник НТУУ «КПІ» - 2009. - № 6. - C.421-425

4. Веременко, I. А. Моделювання динаміки роздрібних цін на ринку нафтопродуктів України / Веременко І. А., Гальчинський Л. Ю. // Бизнес Информ. - 2010. - №1. C. $20-26$

5. Galchynsky, L. The agent-based model of regulation of retail prices on the market of petroleum products / Galchynsky L., Svydenko A., Veremenko I. // Polish journal of management studies. - 2011. - C.136-146

6. Рябцев, Г.Л. Державна політика розвитку ринку нафтопродуктів в Україні: формування та реалізація: монографія / Г.Л. Рябцев - К. : НАДУ, 2011. - 416 с.

7. OPEC Annual Report 2009 [Электронный ресурс] / Organization of the Petroleum Exporting Countries, Public Relations and Information Department - Режим доступу: www.opec.org/report-2009.pdf - Дата доступу: 30.03.2012

8. Enders, W.. Unit-root tests and asymmetric adjustment with an example using the term structure of interest rates / Enders W., C.W.J. Granger. // Journal of Business \& Economic Statistics. - 1998. - Vol. 16(3). - p 304-311. 